\title{
Djibouti's Foreign Policy Change from Survival Strategy to an Important Regional-Power Player: Implications for Ethio- Djibouti Relations
}

\author{
Tafesse Olika*
}

\begin{abstract}
This paper examines Djibouti's emerging active regional foreign policy in the postGouled era. The study has multi-pronged strategy: First, it outlines the underlying factors for Djibouti's emerging as an important player of regional-power politics, while at the same time questioning its viability against the backdrop of its domestic political and economic situation; second, it explores the potential implications of Djibouti's emerging active regional foreign policy for Ethio-Djiboutian relations; finally, it suggests a viable foreign policy Djibouti needs to pursue towards its neighbouring states of the Horn of Africa, a region of security complex. The paper is important for students interested in the history and contemporary African politics in general and the Horn of Africa in particular. It can also serve as additional source of information for policy decision-makers of Ethiopia and Djibouti.
\end{abstract}

Keywords: Djibouti, foreign policy activism, security complex, military base, regional-power politics, major power, emerging power, strategic magnet

DOI: https://dx.doi.org/10.4314/ejossah.v14i2.5

*Assistant Professor, Department of Political Science and International Relations, Addis Ababa University, Email: bonjaephrem@gmail.com, Tel: +251911734453, P.O. box: 1176/ Addis Ababa

This work is licensed to the publisher under the Creative CommonsAttribution-NonCommercialNoDerivs License. 


\section{Introduction}

Djibouti, the smallest Horn of African nation, has begun pursuing a policy of an important player in regional power politics. Being the tinniest nation, Djibouti has to, among other things, take care of survival of its independence and politicomilitary security in this conflict hot-bed region, where unstable politics, dismemberment of states (Somalia being the worst case), displacement of millions of people, mismanagement of economic resources, and hunger and famine have been frequented. The Horn of Africa has been/and is where proneness to conflict and instability exacerbates poverty and backwardness, thereby imposing existential threats originating from both the involvement of external powers and destructive rivalries exist at regional (local) levels. These levels of complex relations make security threat concern the primary objective of foreign policies of the states in this part of Africa. In view of political realists, 'self-preservation', among other things, is an important imperative for small states such as Djibouti.

However, the anomaly in the Horn of Africa has always been that the subregion is where small and weak states tend to use power as instrument of foreign policy whereas the relatively strong ones exercise restraint. Indeed, the Horn of Africa is where win-win diplomacy has been destined to failure because of smaller states' persistent tendency towards playing 'regional-power politics'. The best example of this is the stalemate between Eritrea and Ethiopia after their 1998-2000 war that persisted unaddressed until very recently.

This paper examines the emerging foreign-policy activism of Djibouti and its implications for Ethio-Djibouti relations. The paper aims at: first, to understand and explain the idiosyncrasy (misperceptions and decisions) of the Djiboutian leadership in designing the country's foreign policy and conducting its diplomacy; second, to assess the emerging policy activism of Djibouti and the policy's implications for economic health and political survival of the tiny Horn of African nation; and third, to recommend that Djibouti need to pursue a foreign policy dominated by pragmatism towards its Horn neighbouring countries, particularly Ethiopia.

\section{Djibouti's Raison d'etre: Brief historical Background}

The invention of Djibouti and its continued existence owe to foreign interests and foreign aid (MRGI, 1997, p. 404; Inter-Africa Group, 2000, p. 3). Djibouti's birth as a sovereign state was the outcome of French involvement in north-eastern part of Africa, stimulated by Anglo-French rivalry in the mid- $19^{\text {th }}$ century for control of entrance of the Red Sea. Initially, the French interest was in Obock port, from where French control extended stage by stage to the territory now called Djibouti. 
The French interest in the African shores of the Red Sea began with Rochetd'Hericourt's exploration from 1839-42, marking the beginning of the French colonization of Djibouti. Subsequently, French explorers, using the diplomacy of deception, concluded "treaties of friendship and assistance" with Afar sultans, from whom they purchased the anchorage of Obock in 1862 (MRGI, 1997, p. 404).

In the closing years of $19^{\text {th }}$ century, the Anglo-French rivalry had been intensified thereby marking the French interest on Djibouti a counterweight to the British in Aden (Dolley, 1987, p. 402). Dolley further argues that the presence of British in Egypt and the opening of Suez Canal in 1869 led to the growth of French interest in the area. Subsequently, from 1884 to 85 France expanded its protectorate to include the shores of the Gulf of Tajoura and the Somaliland. It also moved the administrative capital from Obock to Djibouti in 1892 and named it 'French Somaliland' in 1896. By concluding boundary agreement with Emperor Menelik in 1897, France marked out the border between its protectorate and Ethiopia and thereby consolidated its possession of Djibouti. Leonce Lagarde, who developed close relations with king Menelik of Shoa, began a long administrative career at Djibouti (Spencer, 1984, p. 28). The 1897 boundary agreement was also reaffirmed by 1945 and 1954 eventually leading to its independence in 1977.

Djibouti's path to independence was, in fact, full of twists and turns: It combined anti-colonial struggle and decision for continued colonial rule, domestic ethnic rivalry, regional politics and policy of the colonial power. In June 1956, a territorial assembly was established by Overseas Reform Act and represented in an executive council, whose task was to advise the French-appointed governor general. In July 1957, the French Somaliland was given a semblance of selfgovernment. France recognized the peoples of Djibouti to join the French community of an Overseas Territory and they were entitled to representation by one deputy and one senator in the French Parliament, and a counsellor in the French Union Assembly. This status continued until the 1958 and 1967 referenda in which the Afars, "with French encouragement," preferred to continue under colonial administration while the majority of the Issa group wanted independence (Dolley, 1987, p. 402). Following President de Gaulle's visit to the territory in 1966, another referendum was held in March 1967, when 60 per cent of the territory's people voted to continue association with France. The majority of those who preferred continued association were the Afars. The reason why the Afars voted to remain under French colonial rule, arguably, was to avoid incorporation to Somalia and Ethiopia. Subsequently, the territory was re-named the French 
Territory of the Afars and Issas (FTAI), and this was to reflect the interest of the Afars.

This status continued until 1975, when France, forced by a host of developments that unfolded after the end of WWII, began to reconsider the need for granting independence to Djibouti. Already by the early 1970s, political violence in Djibouti demanding for independence, and the pressure from the Organization of African Unity (OAU) was forcing France to change its policy (Inter-Africa Group, 2000, p. 4). In 1976, the territory's citizenship law, which favoured the Afars, was revised, this time in favour of the numerically strong Issa Somalis (Inter-Africa Group, 2000, p. 4). In the referendum held on May 8, 1977, majority of people preferred independence. The Republic of Djibouti was born on June 27, 1977.

The invention of Djibouti thus becoming a fait accompli, Hassan Gouled Aptidon, an Issa Somali, became the first President. The position of Prime Minister was given to Ahmed Dini, an Afar politician (Schraeder, 1993, p. 206). President Gouled ruled the Republic of Djibouti for two decades until he was succeeded by Ismail Omar Gelleh, also Issa Somali. Born and grown up in Dire Dawa, Ethiopia, Mr. Ismail Omar Gelleh was Chief of Staff and Head of the Security in the government of President Gouled for 20 years. Mr. Gelleh was elected to the position of presidency in 1999 with 74 per cent as the candidate of People's Rally for Progress (RPP), the ruling party.

\section{The Post-Independence Djibouti: Socio-Economic and Political Overview}

The Republic of Djibouti is the smallest East African nation with land area of 23,200 sq. km, and a population of 830,000. It is bordered by Eritrea, Ethiopia, and the self-governing territory of Somaliland. The tiniest nation whose population spans frontiers separating these states, Djibouti is situated just beside the Strait of Bab-el-Mandeb (the maritime chokepoint) and, therefore, is the strategic gateway to the Red Sea (Styan, 2013). The Issa Somali and the Afar are the two principal population groups of Djibouti. Whereas the Afars inhabit the northern part of the country, the Issa Somalis reside in the southern part and also are dominant in the Djibouti capital. Although both the Issa Somalis and the Afars are Muslim and Kushetic language-speaking groups, they are arch rivals over resources (Lewis, 1997, p. 353). 


\section{Socio-Economic Condition}

Traditionally, the Afars and Issa Somalis are pastoral communities who roamed across large areas of land without any regard for political boundaries south of the Sahara (MRGI, 1997, p. 404; Lewis, 1997, p. 353). As aforementioned, these two main population groups are in conflict with each other despite the fact that they are related in religion and language. The territory of Djibouti is mostly arid land, with only about 6,000 hectares are arable, less than 10 per cent is rangeland, and there is hardly any woodland left (Markakis, 1998, p. 81). Markakis further argues that the country's agriculture and industry are little developed due to unskilled labour, limited natural resources, and harsh climatic conditions.

The major economic activities of Djibouti are service industries that include banking, sea port, airport, and the operation of Addis Ababa-Djibouti railway. The country's strategic location at the meeting point of the Red Sea and the Indian Ocean has naturally placed it on the busiest trade route between the Mediterranean Sea and Indian Ocean, through which roughly 60 per cent of all commercial ships of the world pass.

Close proximity to large Ethiopian market and existence of expatriate community are also Djibouti's important assets. Djibouti Port is the transhipment for Ethiopia's foreign trade. Particularly after Ethiopia rerouted its freight following the 1998-2000 Ethio-Eritrean War, business soared at Djibouti Port.

\section{Nation and State Building: Challenges for Multiethnic States}

Djibouti is a post-colonial multiethnic state that faces the challenges of nation building and state building. There is asymmetry in the distribution of key resources between the two major population groups of Djibouti. It is the Issa Somalis that dominate the politics and economy of the country. Dolley (1987, p. 402) argues that this is because of their greater size particularly in Djibouti City, the country's economic and political power centre. Dolley further argues that this numerical size of the Issa group in Djibouti town made the colonial power name the territory 'French Somaliland'. The colonial power regarded the Afar group as less urbanized and marginalized them.

When independence came in 1977, the League for the Independence of Afars and Issas (LPAI) dominated the country's political scene. Hassan Gouled Aptidon (an Issa Somali) became President, and the post of Prime Minister was left for the Afar, and Ahmed Dini took the post (Dolley, 1987, p. 402-403). The trend of giving the Afar group secondary status in the country's political structure has continued unaddressed. This has been the root cause of civil war in 1991. The civil war raged between the government forces and the Front for Restoration of 
Unity and Democracy (FRUD) until 2004, when President Gelleh signed peace accord with Ahmed Dini, the veteran Afar politician.

\section{Djibouti's Foreign Policy and Relations}

\section{President Gouled's Foreign Policy: Strategy for Survival}

During the incumbency of president Gouled, Djibouti's survival was under security threat that originated regionally. Djibouti was sandwiched between Ethiopia and Somalia, both being its bigger neighbours and themselves in conflicts. Hence, how to establish and sustain friendly relations with those Horn countries was vital concern of Djibouti's foreign policy. As Murison (1999, p. 337) states, Djibouti's Issa dominated authorities were looking at Ethiopia with disfavour and suspicion for the allegation that Ethiopia had been sabotaging its independence for fear of Issas aspiration for unity with Somalia. Upon independence, President Gouled declared that the objective of Djibouti's foreign policy is preserving its independence and he vowed positive neutrality during the 1977/78 Ogaden war between Ethiopia and Somalia (MOFA DOC, 2000, p. 144; Woodward, 1996, p. 112). As Dolley (1987, p. 403) also argues, "Djibouti has maintained a rigidly neutral stance between the opposing forces of Ethiopian and Somali nationalism, banning sales of military equipment...to both sides and offering its services as a peace mediator." In practice, however, Djibouti was oscillating depending on the balance of power between Ethiopia and Somalia. During the early period of the war, Djibouti was supporting Somalia. The Somali invading forces used Djibouti as a conduit for arms and personnel, whereas the Ethiopian airlines were not allowed to land in Djibouti (MOFA DOC, 2000, p. 215). Later, when power balance changed in favour of Ethiopia, Djibouti assumed a gesture of mediator. Ethio-Djibouti relations improved after the end of the Ogaden war, but not significantly as they were supporting each other's insurgency movements.

Relations between Ethiopia and Djibouti got strengthened after the Ethiopian Peoples' Revolutionary Democratic Front (EPRDF) came to power in 1991. A series of efforts have been made to that effect. Exchanges of visits at summit level were frequented, and in the years 1993 and 1994 joint ministerial commissions meetings took place in order to discuss outstanding bilateral issues (Mulushewa, 2005, p. 44-45). Various agreements were reached on issues of mutual interests including diplomatic, economic, defence and security, refugee repatriation, and extradition of offenders (MOFA DOC, 2000, p. 215). Following the agreements Djibouti was also expected to return the military weapons that the Derg's evacuating army took. Derg officials, such as Captain Melaku Tefera who 
was accused of 'genocide and crimes against humanity' were handed over to the EPRDF government. The Ethiopian government reciprocated, repatriating Djiboutian refugees to their homeland in 'safety and dignity'; Ahmed Dini, the veteran Afar politician and faction leader of FRUD, who was residing in Ethiopia, was 'politely made to leave the country' and he went on exile to Paris (Mulushewa, 2005, p. 47). Also, as a gesture of good neighbourhood, Ethiopia stated its intention to fund the Djiboutian government efforts to improve the services of the Port of Djibouti and the Addis Ababa-Djibouti Railway (CDE, 1997, p. 9).

In its relations beyond the Horn of Africa, Djibouti pursued a policy of 'Multiple Identity'. Djibouti permanently maintained French troops in its territory. It expanded bilateral and multilateral relations guided by a foreign policy dominated by pragmatism. It established bilateral relations with different countries and became member of different regional and global organizations. Djibouti became member of OAU (renamed AU), the Non-Aligned Movement, the League of Arab States and the UN. In 1986, when IGAD was established, Djibouti hosted the founding conference and became permanent seat of the Organization's Secretariat.

President Gouled emphasized Djibouti's Arab identity, stressing common Islamic allegiance of the Afars and Issa Somalis. This was part of his diplomatic efforts to solicit support of Arab states, which, he believed, would be necessary to ensure his country's viability. The continued French military presence in his country, his pragmatic foreign policy of "positive neutrality", and his endeavours to diversify his country's foreign relations enabled Djibouti to gain and maintain relative peace and stability in the Horn of Africa.

It should therefore be reiterated that regional disorder as well as domestic instability due to lack of genuine power-sharing arrangement in the tiny multiethnic nation shaped the contours of President Gouled's foreign policy and the conduct of diplomacy. Diverging ethnic interests coupled with government policy of exclusion of the ethnic Afar have been the domestic foundations of his foreign policy. Put differently, skilfully designed and pursued foreign policy succeeded in preserving Djibouti's autonomy and security in this very rough subregion of Africa. However, this could not stop regime change that brought $\mathrm{Mr}$. Ismail Omar Gelleh to power in 1999. 


\section{Gelleh's Foreign Policy: Strategy of playing Regional-Power Politics}

From the outset President Gelleh, characteristic to his diplomacy, has made his intention clear: He wanted to change Gouled's foreign policy. The previous Djiboutian regime's diplomacy of weak states gave way to Gelleh's foreign-policy activism. The incumbent Djiboutian government began active involvement in regional power politics by hosting Somali national reconciliation conference. He facilitated the Arta Conference, which established the Transitional National Government (TNG) of Somalia. President Gelleh's rhetoric of seeking "cooperation among port authorities in the surrounding region" ended up in transferring the management of the Port of Djibouti to Dubai Ports World in 2000 under a 20-year concession agreement.

The emerging Djibouti foreign policy activism is prompted by the incumbent President's belief to ensure his country's strong presence in the Horn of Africa, the Gulf States and the West, and thereby build and enhance its prestige and influence (Ofcansky, 2001, p. 445). He commenced and intensified personal diplomacy, shuttling in Africa and the Gulf area. In May 1999, he attended a meeting of the Common Market for Eastern and Southern Africa (COMESA) in Kenya. Djibouti is one of the founding members of COMESA, but dropped its membership complaining the Common Market was not making tariff reductions required by member states. Then Djibouti wanted to renew its membership. Arguably, the objectives of renewing Djibouti's COMESA membership have been: first, to show the country's economy has achieved competitiveness regionally; secondly, and perhaps most importantly, its President wanted to compensate for the declining of the French aid to Djibouti.

In January 2000, Djibouti and Libya made a deal on education and scientific cooperation. In the same month, President Gelleh attended a meeting with President Mubarak in Cairo and discussed ways of improving bilateral political and economic relations with the Egyptian leader. In the same year, in a summit meeting in Sana'a (Yemen) Djibouti, Sudan and Yemen discussed issues of security, political, economic, and social cooperation. In May 2000, President Gelleh paid official visit to the United Arab Emirates. At the top of President Gelleh's agenda in all this shuttle personal diplomacy was to secure diplomatic support for Djibouti's Somali national reconciliation initiative (Ofcansky, 2001, p. 445). His active involvement in the Somali issue, arguably, has not been to bring tranquillity to Somalia, but to redefine Djibouti's foreign policy on the Horn of Africa. In short, it was the strategy of becoming an important player in the regional-power politics. More importantly, Djibouti's policy on the Republic of Somalia was to short-circuit Ethiopia's IGAD mandated mediation efforts to 
reconcile the warring factions in Somalia and help reconstruct that country. Indeed, Djibouti was to display influence on Ethiopia that has been exposed to the geopolitical projection of its neighbouring harbour countries since 1991, when the independence of Eritrea rendered it landlocked. On the other hand, Somalia (because of the failure of its state apparatus) became a battle ground for proxy war between the neighbouring countries: Ethiopia, Eritrea and Djibouti. The military intervention of Ethiopia in Somalia in 2006 added a new dimension to geopolitics of the region. A would-be peaceful Somalia meant diminishing Djibouti's influence as port service provider to Ethiopia.

\section{Factors for the Foreign Policy Activism}

There are a host of factors for the emerging Djibouti's foreign policy activism. The major factors are discussed as follows.

- The event of September 11, 2001 has given the Djiboutian government "moral and diplomatic stature" to embark on pursuing active foreign policy. The 9/11 terrorist attack on America was a bonanza for Djibouti. The relationship between US and Djibouti has always been good as the government of Djibouti has generally been supportive of U.S. and Western powers' geopolitical and geostrategic interests in the area, as demonstrated during the Gulf War of 199091. In a similar fashion, President Gelleh's government took a pro-active stance from among Arab League members and supported the anti-terrorist efforts of US. In fact, in order not to risk support of the Arab World, he objected US's unilateral military action against Iraq in 2003 while still allowing the U.S. and its allies to construct military bases in his country (Styan, 2013).

- State collapse and disintegration in Somalia is another factor. The 'state failure' in Somalia removed, at least muted, the "Greater Somalia" idea, the policy to reinvent a Somali state by unifying all Somali-inhabited Horn areas including Djibouti, Ethiopia's Somali Region and Kenya's Northern Frontier District. Particularly for Djibouti the collapse of Somalia removed its psychological fear of being swallowed by its big neighbours (Somalia and Ethiopia). The state failure in Somalia also removed for Djibouti the possible competition for customers of port use. In other words, Somalia in conflict and chaos means that it will be unable to attract others' eye for port use.

- Ethiopia rerouted to the Port of Djibouti as a result of the 1998-2000 EthioEritrean War. Before the war, Ethiopia was using the Eritrean ports. After the 
war, competition for Ethiopia's port use made relations between Djibouti and Somaliland, the self-proclaimed independent de facto state uneasy. Both entered into war of words, each trying to lure Ethiopia for its port use. For example, the late President Ibrahim Egal of Somaliland, reportedly , considered Ethiopia as:
"A major pawn of the region with a necklet of smaller states round her neck, ringing (her) off from the sea." With regard to the role of superpowers in the sub-region, particularly that of France without mentioning by name, he saw the presence of French military force in the region as "an unofficial guardian of regional stability" and if "the hospitality of the hosts of these forces is eroding", he was ready to "offer the French alternative facilities and the unreserved hospitality of the Republic of Somaliland." (Indian Ocean Newsletter, 1998)

This was a response to the statement Mr. Gelleh made in 1998, with a capacity as the Cabinet Chief of President Gouled government, saying:
Djibouti must not be a prisoner of its colonial history and suggested strategic alliance with Ethiopia and the dismantling of any foreign military bases which might pose a danger for the security of the region, and concluding that whilst 'sooner or later France would quit the region', neighbouring countries would still be there. (Indian Ocean Newsletter, 1998)

Be that as it may, the statement of Mr. Egal was a multi-pronged strategy. First, it was intended to lure France and Ethiopia for recognition of Somaliland. Secondly, it was to attract Ethiopia's use of Berbera port. Thirdly, it seems that Egal had been disturbed by growing Ethio-Djibouti bilateral relations. But, on the other hand, given the lack of regional policy on utilization of resources for mutual development and security among the states of the Horn of Africa, Gelleh's proposal for 'strategic alliance with Ethiopia', despite rhetoric, could not develop as supposed to have been. Tensions have been frequent between them.

- The 1998-2000 Ethio-Eritrean War is the other factor. Medhane argues that Djibouti and Sudan are consumers of peace (Medhane, 2004). Conflicts between the Horn states have always been beneficial to Djibouti in terms of security and economy. The 1977/78 Ogaden war between Ethiopia and Somalia and the 1998138 
2000 War between Ethiopia and Eritrea are the best examples. The continued stalemate between Ethiopia and Eritrea until July 2018 has been the most relevant. Following the war Ethiopia rerouted foreign trade to Djibouti Port. Afterwards, it has been Djibouti that handles Ethiopia's import-export trade in the form of monopoly. This, besides contributing significantly to its annual revenues, has given the tinniest Horn nation diplomatic moral stature to pursue assertive regional foreign policy.

- There is also the factor of foreign military bases. A host of foreign powers currently are active in constructing military and naval bases in Djibouti for geopolitical and geostrategic considerations. The American, European and Asian global powers as well as some Middle Eastern states are interested in the control of the strategic Red Sea and Indian Ocean area. This has turned Djibouti into a chessboard for the foreign powers. This is the cost Djibouti has been paying for its strategic location with its capacity of small-state status. Regarding the benefit of foreign military bases in Djibouti it is possible to say two things. First, their military surveillance has provided Djibouti a semblance of peace and stability. As far as this author's information goes, Djibouti, so far, has not become target of international terrorist activities. This makes Djibouti unique in the Horn of Africa, the other exceptional state being North Sudan.

In any case, incumbent upon the Djiboutian government is to know that the expansion of foreign military bases would not be a long-term guarantee for Djibouti's secured existence as sovereign state. The involvement of foreign powers in strategically important regions like the Horn of Africa has potential effect of alienating regional states from one another. Therefore, what is important for Djibouti is not alienation but alliance with its immediate neighbours. Alienation is a recipe for vulnerability to potential national security threat. Indeed, nobody knows who really is controlling Djibouti. This has become a serious cause of concern for Horn countries such as Ethiopia that has direct interest in Djibouti nowadays (FDRE, 2002).

\section{Djibouti's Potential Vulnerabilities \\ The Problem of the Afars of Djibouti}

Following the 2000 peace accord with the Front for the Restoration of Unity and Democracy (FRUD), there is a relative tranquillity in Djibouti. Nevertheless, conflict situation in the country is still imminent (Kebede, 2005, p. 84-85). One of the factors for this is the continuing marginalization of ethnic Afars from the 
country's political and economic affairs. The Afar grievance has been overshadowed by the presence of foreign military bases in the country. For example, Djibouti is one of the key allies of the US in the Horn of Africa. The imminence of conflict due to ethnic tension does not seem to attract the attention of the US.

Djiboutian government's policy that favours the Issa Somalis has also become source of attraction for people of Somali origin to flock into Djibouti, thereby exacerbating the already precarious situation of the ethnic Afar people there. As Markakis (1994, p. 217) correctly notes, "Access to state power is essential for the welfare of subjects". In Djibouti, state power is not accessible for Afars and Issas equally. This means the politically marginalized Afars also are disadvantageous economically. For Ofcansky (2000, p. 440), "as government entrenched a nominal proportionality, the Afars have been discontented". Hence, the Djiboutian Afars demand for power-sharing arrangement on the basis of democratic system of government which is the issue that stands to be addressed yet.

Domestic politics and foreign policy of a state are interrelated, reinforcing each other. This implies that a country's domestic politics influences the foreign policy it pursues towards other countries. This taking spill-over effect into account is particularly so in the Horn of Africa where the states are interdependent in many ways. The Horn of African states, among other things, have inter-ethnic ties. As a result, anything that happens to an ethnic group in one country shapes policies of neighbouring countries. This does not, however, mean that ethnicity do always matter in foreign policies of Horn states. It rather means the states securitize interests of ethnic groups that cross national borders. Regarding this, there are instances with respect to the Afar group in Djibouti. Three major facts are described here.

1. In the 1958 and 1967 referenda the Afar of Djibouti, as aforementioned, voted to continue under colony. This was not only for fear not to be dominated in independent Djibouti, but also not to be incorporated by Somalia (Dire, 1992, p. 420). The decision has also been influenced by the Ethiopian Afar elites favoured by the Imperial government of Haile Selassie (Kebede, 2005).

2. Before the 1974 Revolution, "Ethiopia's policy towards Afar was to neutralize them from the Eritrean struggle for secession and keep Djibouti within the Ethiopian influence to secure its economic and strategic interests through the help of influential Afar elites" (Shehim and Searing, 1984, p. 214). For example, the 
government of Haile Selassie claimed Djibouti on the basis of ethnic, geographic and economic grounds. At a conference held in 1966, the Emperor spoke:

[O]f the people, who the majority compose the population of the territory (Djibouti) are extension of the people of Ethiopia and are therefore Ethiopians. [T] he destiny of the people of Djibouti cannot be decided without Ethiopia's interference (Ministry of Foreign Affairs, 1966, p. 1).

As can be observed, the Emperor's speech was in reference to ethnic ties between the Afar groups in Ethiopia and Djibouti, making it explicitly clear that what happens against the Afars in Djibouti would concern Ethiopia. Subsequently, the Djibouti Afar Liberation Movement (MLD), which demanded 're-unification of Afars', was allowed to operate in Dire Dawa, Ethiopia along with financial backing" (Tholomier, 1981, p. 85; Thompson and Adloff, 1968, p. 85). However, the Emperor's policy was not accepted by the Afars perhaps because of the then 'Christian Amhara and Tigrian dominated politics' of Ethiopia. After the revolution of 1974, the condition of the Afars of Ethiopia has been in perpetual change. The Derg regime, albeit belatedly, recognized regional autonomy for the Ethiopian Afar region. Since 1991, the Afar Region is one of the nine constituent regions of the Federal Democratic Republic of Ethiopia. The impact the developments in Ethiopia would have on attitudes of the Afars of Djibouti and Eritrea is outside the purview of this paper.

3. Driven by its formal Marxist ideology, the Derg regime renounced Ethiopia's claim over Djibouti. Moreover, to the dismay of Ali Mirah, the powerful Afar Sultan and Haile Selassie's most favoured traditional Afar leader, the Ethiopian military government passed legislation nationalizing rural lands in 1975. In so doing, the Derg "ignored heavy security risk" (Kebede, 2005). In May 1976, the Derg issued a Programme of National Democratic Revolution (NDR), recognizing the right of 'regional autonomy' for nationalities in Ethiopia. The implementation of this was delayed until the end of 1980s. Subsequent to the declaration of NDR, a pro-Derg Afar National Liberation Movement (ANLM), the splinter group of the Afar Liberation Front (ALF) that was led by Sultan Ali Mirah, was allowed to operate from Ethiopia. The ANLM pursued a policy of creating "an autonomous Afar State within the borders of 'Free-union Ethiopian Nations' (ANLM, 1976, p. 6; Kebede, 2005). According to Shehim and Searing (1980), the ANLM policy resembled plans of Ethiopian Afar elders, who were petitioning Emperor Haile 
Tafesse Olika

Selassie demanding an "Afar State" that would have mutual benefits for the Afars and the Ethiopian state. The stated aspirations included:

a more and equal distribution of social services and education among ethnic groups, as a pole of attraction for the Afar of Djibouti who would seriously consider joining Ethiopia as an alternative to absorption into a "Greater Somalia", and aid in the pacification in the province of Eritrea by detaching the Afar regions and ... assure access to the Port of Assab. (Shehim and Searing, 1980, p. 224)

The plan, however, was not implemented for the obvious reasons. Kebede (2005, p. 93) argues that the goals the Afar elders outlined have been 'seriously considered by the last two successive Ethiopian regimes': the Derg and the EPRDF. But Kebede's argument can be questioned on the grounds that both the Derg regime's policy of 'regional autonomy' and the EPRDF regime's selfdetermination including and up to secession sought for political expediency of the respective regimes. In short, the policies of the regimes have not been designed to implement the plan of the Afar elders. The Derg regime's policy of regional autonomy was sought to silence dissident movements against its policies. The EPRDF regime recognized the right of self-determination for nations and nationalities of Ethiopia, and instituted nine constituent states -of which one is the Afar region - of the Federal Democratic Republic of Ethiopia with self-governing status and participation in federal affairs. In practice, however, none of these have been moving in the right direction. Details of the constitutional stipulation vs. actual practice on the ground are beyond the scope of this piece. Be that as it may, however, one thing is true: the condition of Ethiopian Afars is far better than that of their kith and kins in Djibouti and Eritrea. The Ethiopian Afars, arguably, are better placed to influence the policy of the Ethiopian government towards the Afars in other parts of the Horn.

To recapitulate, the problem of the Afars has continued in independent Djibouti. President Gouled forced many Afars out of his government and national army in favour of Issa Somalis (MRGI, 1997, p. 404). The exclusion resulted in civil war in Djibouti between the Afars based FRUD and the government from 1993 to 2000. This was a war that a country like Djibouti could not afford. The government, initially, was unwilling to enter talks with the FRUD, thereby leading the country to lose financial aid from France as well as political and moral support 
of Horn states. Pressed externally, the government signed peace accord brokered by Libya in 2000 .

Despite peace deal, it doesn't seem that the grievance of the ethnic Afar in Djibouti has been addressed. Should this continue, Djibouti will continue to be vulnerable to another civil war, which will have repercussions on policies of its neighbours (Ethiopia and Eritrea) that have Afar constituency. Particularly, Djibouti cannot ignore maintaining healthy relations with Ethiopia.

\section{Ethio-Djibouti Relations}

Relations between Djibouti and Ethiopia have been cordial. This is despite Djibouti's harbouring fear of its 'big neighbours', particularly with a memory of Addis Ababa's alleged scheming with France against its independence from French colonial rule (Amare 1989, p. 484). Amare further explained:

The government of Haile Selassie sided with France over its refusal to de-colonize Djibouti for fear that a Muslim Djibouti will succumb to the pressures of, and be controlled by Ethiopia's enemies, thus depriving it of a major outlet to the seas.

After 1975 the military junta that overthrew Haile Selassie's government accepted Djibouti's independence with the proviso that independent Djibouti would not embark on anything that would harm Ethiopia's interest in Djibouti. After independence, the two countries established bilateral diplomatic relations and exchanged resident missions. The relationship has been particularly strengthened after 1998, when Ethiopia rerouted to the Port of Djibouti. Joint ministerial and commission meetings were frequented. A series of agreements were reached on issues of mutual interests including economic, political, military, security (Hassabie, 2005, p. 35-38). Nevertheless, relations have not been fault-free; there were tensions particularly relating to transit issues. The transit tensions mainly have been owing to the fact that Djibouti transferred the management of its ports to the DP World under a 20-years concession. The agreement was signed in 2000. Djibouti's emerging foreign policy activism is also part of its efforts to rival Ethiopia on Somali national reconciliation issue.

Regarding the issue of Ethiopia's transit to the sea it is important to put the current Ethio-Djibouti relations in historical perspective. Ethiopia is the oldest nation in Africa and one of the few largest in terms of territory. On the other hand, it is the only north-eastern African nation to experience the challenges of landlockedness at varying times in its history. With the advent of different foreign 
powers in this region beginning from $16^{\text {th }}$ century, Ethiopia has been time and again divorced with the Rea Sea and the Indian Ocean coasts (Petridis: 1969, p. 135-36).

Consequently, the quest for secure access to the sea has been recurrent theme of Ethiopia's foreign policy. Struggles have been made to regain and retain access to ports and coasts of the Red Sea and Indian Ocean. Ethiopian rulers sought to avoid or mitigate the burden of dependency on others for transit and port services. For instance, Emperor Menelik ceded about 12,000 square kilometres territory to France by the 1897 Franco-Ethiopian border agreement. In quid-proquo, France recognized Djibouti as Ethiopia's natural outlet (Petrdis, 1969, p. 5). Marcus (1983, p. 50) argues that "even though entered bilateral agreements with colonial powers that have coastal outposts in the region, Ethiopia never consented to and contented with inter-European treaties and agreements that had the effect of isolating her from the Red Sea littoral." Ethiopian rulers at varying times claimed that Ethiopia's territorial space had been larger, even extending beyond the Horn. In his circular to European colonial powers, Emperor Menelik stated he would not be a 'spectator' when they, coming from afar, were dividing the continent into spheres of influence. This was part of his quest for access to the sea. However, the objectives of foreign powers have always been to frustrate Ethiopia, denying it access to the sea (Bekure, 1993, p. 30).

The advantage of having military weapons superiority allowed Britain, France and Italy to occupy territories and establish outposts at Ethiopia's gates to the Red Sea and Indian Ocean. Following Ethiopia's military victory over the invading Italian army at Adwa in March 1896, they established diplomatic relations and concluded boundary agreements with Emperor Menelik. The boundary agreements fixed the colonial powers to their coastal outposts. On the other hand, the agreements halted Ethiopia's drive towards the sea and rendered it landlocked (Negussay, 1977).

After the end of World War II, the European outposts at Ethiopia's doorsteps to the sea gained independence. The boundary delimitation agreements the colonial powers signed with Emperor Menelik are the ones marking out the borders Ethiopia today has with its neighbours, sustaining its quest for secure access to the sea. Ethiopia's neighbours, except South Sudan, are harbour states. To ensure and secure outlet to the sea Ethiopia needs peaceful relations with those countries. Ethiopia needs a viable foreign policy carefully designed and managed with skilful diplomacy. There have also been problems. First, some states of the Horn of Africa pursued misguided policy towards Ethiopia, harbouring wrong perceptions about its policy intentions on the region. Second, because of its 
strategic importance the Horn of Africa has been/is the most penetrated by external powers for hegemonic drives, thereby making relations between the regional states unhealthy. As a result, at no time of modern political history of this sub-region of Africa, Ethiopia's quest for access to the sea has been resolved permanently. Whoever controlled the Red Sea and the Indian Ocean coasts never desisted from opting to make Ethiopia weak by maintaining its landlockedeness.

In the post-World War II, Ethiopia, with skilful diplomacy and US connivance, regained Eritrea and access to the sea (Bahiru, 1998, p. 145). In 1945, Emperor Haile Selassie met President Roosevelt at the Suez Canal, in Egypt. At the top of the Emperor's list of agenda for discussion with the American President was the issue of Ethiopia's access to sea (Mulatu and Yohannes, 1993, p. 173; Spencer, 1984). From 1941 to 1950 Eritrea was under British military administration. In 1950, UN General Assembly passed a decision to federate Eritrea with Ethiopia and brought the British military administration to an end. Then, Eritrea was federated with Ethiopia as autonomous self-governing entity in September 1952. The Ethiopian government unilaterally began encroaching on Eritrean autonomy, and finally in 1962 incorporated it into Ethiopia as a province. Eritrean nationalists opposed to the unilateral incorporation and started armed struggle to liberate Eritrea. In 1961, the Eritrean Liberation Front (ELF), from which the Eritrean People's Liberation Front (EPLF) splintered in 1975, was established in Cairo, Egypt. Civil war rocked Ethiopia for about thirty years. The independence of Eritrea in 1991 de facto and in 1993 de jure reversed Ethiopia to its landlocked status (Kinfe, 2001a, p. 524-25). From 1991-1998, Ethiopia's main outlets to sea were Assab and Massawa. Assab handled about $80 \%$ of Ethiopia's import-export trade (Henze, 2001; Styan, 2013).

As a result of the 1998-2000 Ethio-Eritrean War, Ethiopia rerouted to Djibouti, which handles about $97 \%$ of Ethiopia's cargo. The transit and port service charge payments of Ethiopia significantly contributed to Djibouti's annual revenues. Despite this, Djibouti's policy towards Ethiopia with regard to port issue is full of twists and turns. This was reminiscent to the French colonial policy. The concern of France was always how to control Ethiopia's foreign trade transited through Djibouti port (Spencer, 1984, p. 32). The following are worth mentioning. France supported Emperor Menelik II when he denounced the Wuchale Treaty, into which Italy had introduced Art.17 to claim Ethiopia as its protectorate. France, although a subterfuge on paper, proposed a treaty of alliance and friendship with Ethiopia. When Ethiopia defeated Italy at Adwa in 1896, France supported Ethiopia with fire arms (Spencer, 1984, p. 31). During the WWI, Italy, violating its treaty of alliance with Germany and Austria, joined the War on the side of Britain 
and France. But in 1917, Italy demanded Djibouti; France; angered by this, renewed its promise of 1897 to Emperor Menelik. The promise was 'if ever France should leave Djibouti, it would be ceded to Ethiopia' (Spencer, 1984, p. 32).

However, this could not survive the test of time and selfish interests. The promises and proposals were frustrated in 1935, when France joined the AngloItalian adventure of handing Ethiopia over to Italy in quid pro quo for anti-Hitler stance. In the same year, France contrived against Ethiopia by allowing Italy to pass all "arms, ammunition and implements of war" through Djibouti port. On the other hand, Ethiopia, whose only access to sea was Djibouti, was refused to transit any weapons through that corridor. As Marcus (1983, p. 51) states, France's refusal to permit Ethiopia arms shipments from the Port of Djibouti to Addis Ababa in 1935 was "the real antecedent of fascist invasion and occupation of Ethiopia in 1936." John Spencer (who agreed with Marcus) argued that France also blocked Ethiopia's use of the Ethio-Djibouti Railway. Spencer explained:

It was degrading to have to respond to the argument that, in a war for survival of an independent country, it was necessary to France to violate an agreement with that country in order to preserve intact for the French government, French banks, and French stockholders investment in that railway. (Spencer, 1984, p. 46)

Independent Djibouti has also made several promises with regard to Ethiopia's use of Djibouti port. In 1981, when the Derg regime began to 'implement' its policy of regional autonomy, Djibouti was declared a free port to Ethiopia. Similar gestures have been made by President Gelleh. To lure Ethiopia's use of Djibouti port, he even went to the extent of proposing economic cooperation and political integration. These, however, have not seen the light of day, being overshadowed by ambitions for regional power. From the economic front, the rhetoric was to recognize Djibouti port as natural outlet for Ethiopia. In practice, the Djibouti leadership frequently has been introducing new tariff rules imposing high rate of transit and port service charge payments on Ethiopia. It is true that Ethiopia is the major Djibouti port user, contributing significantly to the annual revenues of that tiny Horn nation.

To recapitulate, the foreign policy of President Gouled was to preserve the independence of Djibouti. His regional diplomacy was to show the gesture of 'neutrality', non-interference in interstate conflicts. He established a chain of relations to solicit diplomatic support. All this relations of courtship had given the country relative stability and guarantee of existence in this conflict hot-bed region. 
This carefully designed and skilfully managed astute diplomacy could not survive the change of guards in Djibouti. The post-Gouled's Djiboutian leadership has become most ambitious. It seeks active involvement competing for regional power politics. But it is wise for Djibouti to see that this is against its domestic socioeconomic and political reality.

With regard to landlocked Ethiopia, without a viable foreign policy for outlet to sea, it has suffered/will continue to suffer from pressures of powers controlling northeast African seashores. "The strategic objective of the colonial powers in battling over the sea ports in the region was to obstruct the transit of firearms destined to Ethiopia" (Zewde Gabre-Selassie, 1975, p. 201). As aforementioned, Ethiopia's rulers at varying times struggled militarily and diplomatically to regain and retain its legitimate interests on the Red Sea and Indian Ocean coasts. Indeed, the issue of access to the sea has been/is a test for friends and foes of Ethiopia.

For example, central to the Ethio-Djiboutian relations is the issue of Ethiopia's port use. International law of the sea recognizes the right for access to the sea of landlocked countries, but also makes bilateral relations the necessary modality. Ethiopia and Djibouti signed a document known as "Agreement on Port Utilization and Services to Cargo in Transit" on April 13, 2002. As above mentioned, Djibouti however has not been observing the terms of the Agreement. Legal scholars argue that the law among nations is essentially political clothed with legal terminology (Shaw, 2005). In international relations there are two major contending theories: realism and liberalism. In view of proponents of realism, relations among nations depend on relative power position. For the realists the efficiency of international agreement depends on relative capability of contracting party states. The bargaining power of the state with landlocked status vis-à-vis the harbour state is limited. Ethiopia whose nearly all merchandise must pass through Djibouti Port is not an exception. Hence, in the interpretation of the Ethio-Djibouti Agreement on Port Utilization and Services to Cargo in Transit the position of Djibouti prevails.

In contrast, proponents of liberalism maintain that dependency in interstate relations is mutual, based on the principle of give-and-take in good faith. Ethiopia and Djibouti are highly interdependent. Djibouti, in many respects, is 'a flea on Ethiopia's back'. In the hottest months of July, August and September in Djibouti, Ethiopia is a cooling place for Djiboutian citizens. It is also Djibouti's major trade partner (Park, 2005, p. 770). Ethiopia is where Djibouti's bread is 'baked and buttered'. Hence, Ethiopia, in many ways, is in a better position than Djibouti. 
In addition to its being rich in natural resources and human capital, Ethiopia has a long tradition in diplomacy. If the diplomatic capital is put in practice there are accessible alternative ports in north-eastern African region for Ethiopia. Ethiopia has "to consider use of alternative ports of East Africa" (Bekure, 1993, p. 40). It also has to consider conducting astute diplomacy of resources regionalization through scheme of regional integration. It is wise for Ethiopia to regain secure access to the sea through port-lease deal with its harbour neighbouring countries and, if possible, port purchase. Ethiopia, very recently, has started making deals to take share in management of ports with its neighbours. This includes developing ports together with harbour neighbours and foreign company such as DP World. The deal entails Ethiopia will be a shareholder of the ports as well. Besides, it is engaged in providing neighbouring countries with hydroelectricity in quid-pro-quo for port use (Medhane, 2004). This can serve as a short-term strategy for alternative port use. The normalization of the Ethio-Eritrean relations is also an opportunity that has opened a new era.

All the above mentioned unfolding developments have the potential to put Djibouti at the losing end in terms of economy and national security. The country is based predominantly on service economy: port and banking services. Ethiopia with a thriving economy as well as the major user of Djibouti port is indispensable to Djibouti. Secure and developed Ethiopia is useful for Djibouti's economic and national security. Djibouti's transboundary ethnic ties are complex in the Horn of Africa. The Afar and Issas of Djibouti have their kins in Ethiopia, Eritrea and Somaliland. This suggests that Djibouti needs to seriously consider fair powersharing arrangement between the two major ethnic groups of its population.

Since recently Ethiopia has good relations with all its neighbours. The reason why Djibouti has been pursuing a foolish regional foreign policy hanged on the assumption that the damaged Ethio-Eritrean relations would always remain the same. This has proved to be wrong. The Ethio-Eritrean relations have changed for the better following the coming to power of Abiy Ahmed in 2018. On top of that foreign powers' economic and diplomatic support would change in time. The foreign powers' economic assistance and diplomatic support would also cease with the passing of time. The geopolitical and geostrategic calculations of global powers are always in constant flux. But Djibouti and Ethiopia will always remain together as neighbours.

\section{Concluding Remarks: What Policy Options for Djibouti?}

Located at the world's major shipping lanes, Djibouti today has become strategic magnet of foreign powers. In the era of revolution in communication and 148 
information technologies, the importance of strategic location is susceptible to change. In this vein, Djibouti needs to design a viable foreign policy to secure its security internally as well as regionally.

Internally, it is fragile in terms of politics and economy. From the political front, ethnic relations of Djibouti's major population groups do not seem to be healthy, to say the least. The problem of the ethnic Afars of Djibouti has not been addressed. It has persisted, awaiting a democratic system of government established in an environment of free, fair and regular elections. Djibouti has multiparty system and political parties operate. But the multiparty system is a political subterfuge, only necessary for public consumption. For the Afar of Djibouti, the 2000 peace deal is yet to be implemented. From the economic front, the Djiboutian leadership's policy drive is to make Djibouti a prosperous country. Although this is not bad, it is against the reality on the ground. First, the country's economy is based on service industry which is highly susceptible to shocks. A saying goes, 'when Djibouti's transport sector sneezes, the whole economy catches cold'. The civil war in the 1990s did not only damage the country's image as an 'oasis of peace', but also affected it economically (Styan, 2013). Second, the foreign assistance is not also sustainable. In 2000, Djibouti transferred the management of its port and later customs and airport to DP World on the basis of a twenty-year concession agreement (Oneko, 2018; Palin, 2017). The advent of the Dubai Company in the country, it seems, was a rescue mission to Djibouti's service industry. Djibouti also has the fear of French troops withdrawal, which has shaped Djibouti's foreign economic policy since 2000.

Regionally, Djibouti is vulnerable to security threats. To the south of Djibouti is Somalia marked by 'state failure' since 1990s. To the north is Eritrea, with which Djibouti has had military clash as a result of a dispute over Mount Dumera. Immediately across the Red Sea is Yemen, another 'failed state', with spill-over effect. Such a regional environment does not give Djibouti a peace of mind. Djibouti is the smallest in the Horn of Africa that needs to pursue soft-power diplomacy of small states (Cooper and Shaw, 2009). The policy of regional-power politics that Djibouti pursues cannot be a passport to its national security. Djibouti hosts the Headquarters of IGAD Secretariat since the organization's establishment in 1986. This could have served Djibouti as diplomatic capital to design a clever foreign policy managed by astute and skilful diplomacy. In a nutshell, the most important task ahead for the incumbent Djiboutian leadership is to learn from the 'Gouledian' foreign policy and diplomacy. 


\section{References}

Abebe T. Kahsay. (2007). Ethiopia's Sovereign Right of Access to the Sea under International Law (master's thesis).University of Georgia: School of Law.

Alemayehu Abebe. (2005E.C.).Ye Itiopia tarik, kemajameria iske ahunu zemene [Ethiopian history from the beginning up to now]. No place of publication and publisher.

Alemseged Bogale Adal. (1985 E.C.).Ye'Eritra inkoklish [The puzzeles of Eritrea]. Addis Ababa: Bole Printing Agency.

Ali Said. (1998). Afar ethnicity in Ethiopian politics. In Mohammed S. and John M. (Eds.),Ethnicity and the state in Eastern Africa. Stockholm: Elanders Gotab.

Amare Tekle. (1996). International relations in the Horn of Africa (1991-96). Review of African Political Economy,70, 499-509.

Amare Tekle.(1989). The determinants of the foreign policy of revolutionary Ethiopia. The Journal of Modern African Studies, 27(3), 479-512.

Andreas Eshete. (1994). "Why Ethio-Eritrean relations matter: A plea for future political affiliation" in Amare Tekele (Ed.) Ethiopia and Eritrea: From conflict to cooperation. NewJersey: The Red Sea Press.

Araia Tseggai. (1994). "A new perspective of Ethio-Eritrean partnership" in Amare Tekele (Ed.), Ethiopia and Eritrea: From conflict to cooperation. NJ: The Red Sea Press.

Bahru Zewde . (2002). A History of Modern Ethiopia, 1855-1991 ( $2^{\text {nd }}$ ed.). Addis Ababa: Addis Ababa University Press.

Bahru Zewde. (1987). "The historical context of Dogali encounter", in Taddesse Beyene et al. (Eds.), The centenary of Dogali, Proceedings of the International symposium. Addis Ababa: IES.

Bekure Woldesemayat . (1993). Accessibility of East-African ports to Ethiopia. Journal of Development Research, 15(1), 29-54.

Belai Abbai, \& Zeru Kihishen. (2011). Meles' Assab policy threatens Ethiopia's national security. Satenaw News

Retrieved from http://www.ethopins.com/belai and zeru.htm/

CDE (Ethiopia Djibouti Railway). (1999). Facts in the use of the ports of Assab and Massawa up to the detention of Ethiopian property in May 1998. ESL Archives.

Clapham, C. (1996). Africa and the International System: The Politics of State Survival. Cambridge: Cambridge University Press.

Clapham, C. (2006). "Ethiopia", in Clapham, C., Herbst, J., and Mills, G. (Eds.) Big African States. Johannesburg: Wits University Press. 
Clapham, C. (2003). Notes on the Ethio-Eritrean boundary demarcation. East African Forum. Retrieved from http://www.cfeefces.org/code/claph.htm

Clapham, C. (2002). Controlling space in Ethiopia. in James, Wendy et al. (Eds.), Remapping Ethiopia: Socialism and after (pp.9-30). Oxford: James Currey.

Cliffe, L. (1999). Regional dimensions of conflict in the Horn of Africa. Third World Quarterly, 20(1), 89-111.

Cooper, A. F., \& Shaw. M. (Eds.). (2009). The Diplomacies of Small States. New York: Palgrave Macmillan.

Copson, R., W. (1994). Africa's Wars and Prospects for Peace. New York: M.E. Sharpe, Inc.

Dolley, M. (1987). Djibouti. in Africa South of the Sahara. London: Europa Publications.

Dombrowski, F. A. (1985). Ethiopia's Access to the Sea. Leiden/Koln: E.J. Brill, the Netherlands.

EIU. (2002). Country Profiles. London: Economist Intelligence Unit.

Erlich, H. (1996). Ras Alula and the Scramble for Africa. Lawrenceville, NJ; Asmara, Eritrea: The Red Sea Press, Inc.

Erlich, H. (1986). Ethiopia and the Challenge of Independence. Boulder: Lynne Reinner Publisher.

FDRE. (2002). Foreign and national security white paper. Addis Ababa.

FDRE. (1995, August 21). The Constitution of the Federal Democratic Republic of Ethiopia. Federal Negarit Gazeta of the Federal Democratic Republic of Ethiopia. Addis Ababa: FDRE.

Flint, C. (2006). Introduction to geopolitics. London: Routledge.

Getachew Begashaw.(2010). Port of Assab as a factor for economic development and regional conflict. Ethiopian Unity Diaspora Forum.

Getachew Kassa. (2001). Among the pastoral Afar in Ethiopia: Trdition, continuity and economic change. The Netherlands:International Books.

Getachew Kassa. (2001b). Resource conflict among the Afar of North-East Ethiopia in Resource competition and sustainable development in Eastern and Southern Africa (pp. 145-171). London: Pluto.

Getachew Metaferia. (2009). Ethiopia and the United States: History, Diplomacy, and Analysis. York: Algora Publishing.

Gilkes, Patrick. (1993). Analysis: even the camels know this land is one. Ethiopian Review, 3(8), 9-11.

Grygiel, J., J. (2006). Great powers and geopolitical change. Baltimore: The Johns Hopkins University Press. 
Halliday, F. and Maxine M. (1981). The Ethiopian revolution. London; Verso Editions and NCB.

Harbeson, J. (1978). Territorial and development politics in the Horn of Africa: The Afar of the Awash Valley. African Affairs, 77(309), 479-478.

Hassabie Molla.(2005). Landlockedness as a factor for Ethiopia's Relations with neighboring countries (master's thesis). Addis Ababa University, Addis Ababa.

Indian Ocean Newsletter. (1998, May 16). Egal off in Addis. Retrieved from https://www.africaintelligence.com/ion/politics/1998/05/16/egal-off-inaddis, 49537-art

Indian Ocean Newsletter. (1998, May 23). Egal's view of the region. Retrieved from https://www.africaintelligence.com/ion/politics/1998/05/23/egal-sview-of-the-region, 49560-art

Henze, P. (2001). Eritrea's war: Confrontation, international response, outcome, and prospects. Addis Ababa: Shama Books.

Kebede Yimam. (2005). Afar politics and Its impact on inter-state relations of Ethiopia, Djibouti and Eritrea (master'thesis). Addis Ababa University, Addis Ababa.

Kebreab Tasfai. (1987). "The causes and effect of Dogali encounter", in Taddesse Beyene et al. (Eds.), The centenary of Dogali, proceedings of the international symposium. Addis Ababa/Asmara: IES (AAU).

Kinfe Abraham. (2001a). Ethiopia from empire to federation. Addis Ababa: Ethiopian International Institute for Peace and Development Press.

Kinfe Abraham. (2001b). Ethiopia: The dynamics of economic reforms. Addis Ababa: Ethiopian International Institute for Peace and Development Press.

Kinfe Abraham. (2001). Ethiopia: The dynamics of economic reforms. Adds Ababa: Ethiopian Institute of International Peace and Development Press.

Legum, Colin (Ed.). (1979). African contemporary record: Annual survey and documents 1977-1978. New York: African Publishing Co.

Legum C.(1975). Ethiopia: the fall of Haile Selassie's empire. London: Rex Collings.

Lewis, I.M. (1997). Djibouti. in Africa south of the Sahara (26 ${ }^{\text {th }}$ Edition). Europa Publications.

Lyons, T. (1990). "Internal vulnerability and Inter-State conflict: Ethiopia's Regional Foreign Policy.”, in M. Ottaway (ed.), The political economy of Ethiopia. New York: Praeger Publishers

Marcus, H. G. (1994). A history of Ethiopia. Berkeley: University of California Press. 
Marcus, H. G. (1995). The politics of empire: Ethiopia, Great Britain and the United States 1941-1974. New Jersey: The Red Sea Press, INC.

Markakis, J. (1998). Resource conflict in the Horn of Africa. London: Saga Publications LTD.

Medhane Tadesse. (2002). Al-Ittihad: political Islam and black economy in Somalia: Religion, money, clan and the struggle for supremacy over Somalia. Addis Ababa: Mega Printing Enterprise.

Medhane Tadesse. (1999). The Eritrean-Ethiopian war: Retrospect and prospects. Addis Ababa: Mega Printing Enterprise.

Medhane Tadesse. (2004). Turning conflict to cooperation: Towards an energy-led integration in the Horn of Africa. Addis Ababa: Friedrich Ebert Stiftung.

Mesfin Habte-Mariam. (2000 E.C). Itiopia: Ye' Bahr tarafuana bahr hailua [Ethiopia: Its sea frontier and naval force]. Addis Ababa: Ye'Kadmo Bahr-Hail Malayo Labashochna Civil Saratagnoch Meredaja Mahber.

Mesfin Woldemariam. (1999). The Horn of Africa: conflict and poverty. Addis Ababa: Commercial Printing Press.

Minstry of Information.(2002). Foreign affairs and security policy and strategy of FDRE. Addis Ababa: Mega Printing Enterprise.

Morgenthau, H. (1998). Realism and international politics. New York: Routledge.

Morgenthau, H. (1996). Politics among nations: The struggle for power and peace. LA: McGraw Hill.

MRGI. (1997). World directory of minorities. MRGI (Minority Rights Group International.

Mulatu Wubneh and Yohannes Abate. (1993). Transition and development in the Horn of Africa. Addis Ababa: Berhanena Selam Printing Press.

Mulushewa Metekia.(2005). Conflict, competition and cooperation among the countries of the Horn: A Case Study of Ethio-Djibouti Relations since 1977. Addis Ababa University, Addis Ababa.

Murison, K. (2003). Djibouti. in Africa South of the Sahara (23 ${ }^{\text {rd }}$ Edition). London: Europa Publications.

Negussay Ayele. (1977). "The foreign policy of Ethiopia", in Olajide Aluko (Ed.), The foreign policies of African states. London: Hodder and Stoughton.

Ofcansky, T. (2001). Djibouti. in Africa South of Sahara (30 ${ }^{\text {th }}$ Edition). London: Europa Publications.

Oneko, S. (2018, September 23). Arab Gulf States in the Horn of Africa: What role do they play? Deutsche Welle.

Retrieved from: https://www.dw.com/en/arab-gulf-states-in-the-horn-ofafrica-what-role-do-they-play/a-45602930 
$\overline{\text { Palin, M. (2017, September 3). Tiny African country becomes playground for world }}$ super-powers. Retrieved from https://www.news.com.au/world/africa/tinyafrican-country-becomesplayground-for-world-super-powers/news story/0fa72ddc2df6efc9ac437d8681977fd6

Pankhurst, K.P.R. (1964). Ethiopia and the Rea Sea and Gulf of Aden Ports in the 19 th and $20^{\text {th }}$ centuries. Ethiopia Observer, 8(1), 37-104.

Petrides, S. P. (1983). The Boundary Question between Ethiopia and Somalia. New Delhi, India.

Petrides, S. P.(1969). Ethiopia's sovereign right over African coasts of the Red Sea and Gulf of Tadjoura (unpublished paper). Addis Ababa.

POMOA. (1976). Basic Documents of the Ethiopian Revolution. Addis Ababa: POMOA (The Provisional Office for Mass Organizational Affairs)

Reno, W. (2001). "External Relations of Weak States and Stateless Regions in Africa", in Khadiagala, Gilbert M. and Terrence Lyons (Eds.), African Foreign Policies: Power and Process. Boulder/London: Lynne Rienner Publishers.

Rubensen, S. (1976). The Survival of Ethiopian Independence. London: Heinemann Educational Books.

Shaw, Malcolm N. (2005). International Law, Fifth Edition. Cambridge: Cambridge University Press.

Schraeder, (1993). Djibouti. in Africa South of the Sahara. Europa Publications Limited.

Shehim, Kassim. (1985). Ethiopia, evolution and the question of nationalities: The case of the Afar. Journal of African Studies, 23, 2, 331-348.

Shehim, K. and James S. (1980). Djibouti and the quest for Afar Nationalism. African Affairs, 79, 212-223.

Spencer, J. H. (1984). Ethiopia At Bay: Personal Account of the Haile Selassie Years. Algonac/Michigan: Refrence Publications, Inc.

Styan, D. (2013). Djibouti: Changing Influence in the Horn's strategic $h u b$ (briefing paper).Chathan House: Africa Programme.

Tholomier, R.(1981). Djibouti: A Pawn of the Horn of Africa. London: The Scarecrow Press.

Thompson, V., \& Richard A. (1968). Djibouti and the Horn of Africa. Stanford: Stanford University Press.

Vasciannie, S.C. (1990). Land-locked and Geographically Disadvantaged States in the International Law of the Sea. Oxford: Clarendon Press. 
Minstry of Foriegn Afairs . (1966). Verbatim Record of the Press Conference held by His Imperial Majesty Haile Selassie I. Addis Ababa: Minstry of Foriegn Affairs Archive.

WIC (Walta Information Center). (1999). Dispatches from Electronic front: Internet response to the Eritrea-Ethiopia Conflict. Addis Ababa: Mega press.

Woodward, P. (1996). The Horn of Africa: State Politics and International Relations. London: Tauris Publishers, Tauris Academic Studies.

Woodward, P. (2003). The Horn of Africa: State Politics and International Relations. London: I.B. Tauris\&Co.Ltd.

Park, K (Ed.). (2005). The World Almanac and Book of Facts 2005. New York: World Almanac.

Wuhib Muluneh. (1998). "Landlockedness and dependency on coastal countries, the case of Ethiopia", in Hodder, Dick et.al(Eds.). Landlocked States of Africa and Asia. London: Frank Cass Publishers.

Yacob Haile-Mariam. (2004 E.C).Assab ye'man nat? Ye Itiopia ye bahr ber tiyake [To whom does Aseb belong?: Ethiopia's quest for an acess to the Sea] No place of publication and publisher.

Zewde Gabre-Selassie. (1975). Yohannes IV of Ethiopia, A Political Biography. London: Oxford University Press.

Zewde Reta. (1998 E.C). Be'Kadamawi Haile Selassie Ye'Eritra Gudaiy19411963 [Eritrean Afairs during the regin of Haile Selassie (1941-1963 E.C) . Addis Ababa: Central Matemiya Bet. 